\title{
UDC 378.22:007.3
}

\section{Tetiana S. Kravchynska}

$\mathrm{PhD}$ of Pedagogical Sciences, Department of Public Administration and Project Management, Educational and Scientific Institute of Management and Psychology of the State Higher Educational Institution «University of Education Management» of the National Academy of Educational Sciences of Ukraine, Kyiv, Ukraine ORCID ID 0000-0002-7521-3508

tatyana.krav@ukr.net

\section{Irina L. Sidanich}

Doctor of Pedagogical Sciences, Associate Professor, Professor at the Department of Pedagogy, Administration and Social Work, Institute of Management and Psychology of the State Higher Educational Institution «University of Education Management» of the National Academy of Educational Sciences of Ukraine, Kyiv, Ukraine

ORCID ID 0000-0002-2992-3808

2363395@ukr.net

Inna O. Pavlenko

PhD of Pedagogical Sciences, Department of Sports Disciplines and Physical Education,

A. S. Makarenko Sumy State Pedagogical University, Sumy, Ukraine

ORCID ID 0000-0001-5707-7509

byyf1202@ukr.net

\section{Oksana V. Dubinina}

$\mathrm{PhD}$ of Pedagogical Sciences, Department of Public Administration and Project Management, Educational and Scientific Institute of Management and Psychology of the State Higher Educational Institution «University of Education Management» of the National Academy of Educational Sciences of Ukraine, Kyiv, Ukraine

ORCID ID 0000-0002-5405-8502

o_dybinina@ukr.net

\section{CRITERIA AND INDICATORS OF FORMATION OF SECONDARY SCHOOL TEACHERS' READINESS TO APPLY INTERNET TECHNOLOGIES IN THEIR WORK}

\begin{abstract}
The article substantiates the criteria and indicators of formation of secondary school teachers' readiness to use Internet technologies in their professional activity. Modern education reform and the introduction of new educational content encourage teachers to use innovative methods and e-learning text-books, which requires new approaches to teacher training and selfeducation in the inter-certification period. Pedagogical conditions of development of teachers' readiness to use Internet technologies are considered and pedagogical expediency of using Internet technologies in teachers' work is revealed, taking into account the content and specifics of teachers' pedagogical activity in educational institutions. The use of traditional teaching aids along with Internet technologies allows teachers to improve teaching significantly as well as make the learning process more interesting, diverse and intensive. Internet-technologies are an effective means of communication between all participants of the educational process, which is realized through various chats and Internet conferences. Taking into account the specificity of secondary school teachers' professional activity, appropriate criteria and indicators were chosen, namely, motivational, integrative, work-relevant and other criteria. We defined gnostic, project, constructive, organizational, communicative, didactic, managerial, intellectual, research and professional skills, which are crucial for teachers' professional readiness. It is emphasized that the content of motivational, integrative and work-relevant criteria determines the strategy of teachers' professional behavior. On the basis of the above-mentioned criteria and indicators of their manifestation, low, average, sufficient and high levels of secondary school teachers' readiness for the use of Internet technologies in their work are distinguished. It is shown that these criteria and their indicators provide an opportunity to obtain empirical data required for experimental research and to gain pedagogical insights for creating an original technology of formation of secondary school teachers' readiness to use Internet technologies in their professional activity.
\end{abstract}

Keywords: teachers; professional activity; Internet technologies; metrics and levels of readiness for the use of Internet technologies. 


\section{INTRODUCTION}

Formulation of the problem. Social, economic and information-technological transformations, which have been taking place in Ukraine, place new demands on the profession of teacher. New content of education calls for the creation and use of new educational systems, the use of innovative methods and teaching aids, which requires new approaches to teacher training. Teachers are expected to be able to apply modern technological means, which, besides information technologies (IT), include new teaching forms and methods, new approaches to the process of teaching and new means of lesson preparation.

On the one hand, information technology means the development, design and manufacture of computers, their peripherals and components, network equipment and software, and, on the other hand, their use in various systems to store, convert, protect, process, transmit and receive information.

At the same time, Internet technologies are understood as an automated environment for obtaining, processing, storing, transmitting and using knowledge in the form of information by means of the Internet. Although Internet technology is a broad concept, which includes everything that is related to the network, we focus our attention on the Internet technologies that are used in education. They include: computer educational programs (online electronic textbooks and manuals, simulators, laboratory workshops, test systems); network educational systems based on multimedia technologies; intellectual and educational expert systems; distributed databases; telecommunications, including e-mail, teleconferencing, local and regional communication networks, data exchange networks, etc.; electronic libraries and distributed and centralized publishing systems.

Particularly important in this respect is the ability of secondary school teachers to use Internet technologies in their professional activities. In this regard, it should be emphasized that the formation of teachers' readiness to use Internet technologies must meet the requirements of the information society, on the one hand, and of the educational community, employing up-to-date information and communication technologies, on the other. Accordingly, training secondary school teachers to use Internet technologies in their professional activity should be dynamic and continuous, as modern information and communication technologies are being rapidly updated. Therefore, teachers need to constantly improve their professional skills in the use of Internet technologies in line with the changes taking place in the information society.

Teachers' readiness for the use of Internet technologies in their work should be based on a thorough understanding of modern education technologies and is of great practical importance for the development of European-oriented education in Ukraine.

Analysis of the latest relevant research and publications. In the theory and practice of education, different aspects of teacher's professional readiness have been studied, among others, by K. Duray-Novakova, M. Dyachenko, L. Kandybovich, N. Kuzmina, V. Lugovy, V. Molyako, O. Pekhota, L. Pukhovska [1], M Savina, V. Semichenko, V. Slastionina, Yu. Turchaninova, G. Trotsko. Internet technologies as the basis for the formation of a single educational space, teachers' interactions in the educational Internet network "Education Partnership" have been studied by N. Zadorozhna. Teachers' readiness to use information technologies in their work has been highlighted in the works of L. Bilousova [2] and S. Kryshtof [3]. A. Bruhlyshynsky, T. Gabiy, A. Matiushkin, E. Mashbits, A. Petukhova, A. Tikhomirov have investigated the distinctive features of IT-based teacher-student interactions. François Baccelli researched communication network modeling and design [4].

According to academician V. Yu. Bykov, the most common Web 2.0 Internet technologies include: the torrent technology (which provides data transmission), Twitter 
technology (creation, sending and reception of short text messages), blog technology (creation and publication of posts with their possibility of being commented on by other users), wiki technology (creation, publication and edition of articles). Web 3.0 Internet technologies are based on Web 2.0 technologies and serve to create high-quality content and services in open PCM (Ding, Youtube, Funny Or Die, Google Wave). Web 4.0 Internet technologies, which are based on Web 3.0 technologies, have improved functions and support smart automated systems (such as expert, semantic and robotic systems, decision making systems, CAD, GIS and their certain fragments) [5].

The importance of Internet technologies, according to S. D. Kryshtof, is due to their role in obtaining new educational information, inter-user communication, information transfer, information process automation, as well as in various human activities, intellectualization of society, and information society development [3].

German scientists note that cloud computing allows using IT infrastructure, platforms and various applications as electronic services on the Internet [6].

The aim of this article is to theoretically substantiate the criteria and indicators of teachers' readiness to use Internet technologies in their work.

\section{RESULTS AND DISCUSSION}

The pedagogical research under consideration has been carried out as part of the research work "Economic, social and informational mechanisms of formation and improvement of the project management system" (RK 0119U000543) to be conducted in 2019-2021 by the Department of Public Administration and Project Management of the Educational and Scientific Institute of Management and Psychology of the University of Education Management of the National Academy of Educational Sciences of Ukraine. At the same time, the research under consideration has been carried as part of the scientific-practical study "Development of the information-analytical competence of the teacher in the conditions of transformational changes of society", headed by O.V. Dubinina, $\mathrm{PhD}$ (copyright certificate № 93490 of 10/28/2019). The aims of the study include motivating teaching staff for selfdevelopment in various spheres of life, formation of teachers' professional competences for continuous professional development, development of teachers' communication skills and methodological activity, development of teachers' skills in using ICT instruments in professional activities.

The study has used a set of theoretical and empirical methods: theoretical and methodological analysis of relevant scientific works, content analysis to clarify the definitions of the basic concepts of the research, logical generalization, systematization of results, and formulation of the prospects of further research. The properly substantiated criteria and indicators will be used during a special training to assess the level of teachers' readiness for the use of Internet technologies in their professional activities. The analysis of scientific and methodological literature has shown that there are different approaches to the definition of the term "criterion".

The criterion in the general sense is 1) the standard on which decisions, assessments and/or classifications can be made; 2) the level of achievement, which is determined by the degree of goal achievement [7].

N. Plakhotnyuk and A. Fedoruk [8] in their works define criterion as a sign that allows assessing something. S. Ozhegov understands the criterion as the sign of truth or correctness of the situation [9].

O. Barabanschikov and N. Deryugin propose quite ambiguous understanding of the term "criterion". They give four definitions of "criterion": 1) as an indicator, an objective manifestation of something; 2) as the psychological setting of the assessor; 3) as a measure, i.e. 
a rule to be used in making a diagnosis; 4) as a question/item of a questionnaire or a test, etc.

O. Barabanshchikov and N. Deryugin also advise to follow the scientists who believe the concept of "criterion" to be broader in its meaning than the concept of "indicator", the latter being a component of the criterion.

In its turn, the indicator implies the quantitative and qualitative characteristics of the object, describing its specific property [7].

In determining the criteria and indicators of teachers' readiness for the use of Internet technologies, we share O. Barabanschikov's and N. Deryugin's point of view.

Our understanding of teachers' readiness for the use of Internet technologies is based on the holistic approach, which allows treating it both as a system, a single unity, as well as an element of a larger system. That is, it makes it possible to study a research subject from different perspectives [10].

Based on the foregoing, we have identified and proposed six criteria in determining teachers' readiness for the use of Internet technologies: motivational, integrative, workrelevant, value, creative and result-reflexive $[11 ; 12 ; 13]$. The criteria and indicators of teachers' readiness for the use of Internet technologies are given in Table 1.

Table 1

\section{Criteria and indicators of teachers' readiness for the use of Internet technologies}

\begin{tabular}{|c|c|}
\hline Criteria & Indicators \\
\hline Motivational & $\begin{array}{l}\text { - motivation to use modern technologies, in particular the Internet, in their work, } \\
\text { acquisition of knowledge about the Internet and its use in education; } \\
\text { - } \\
\text { - } \\
\text { self-realization ability; }\end{array}$ \\
\hline Integrative & $\begin{array}{l}\text { - knowledge of foreign languages at a proficiency level; } \\
\text { - the ability to select software to use in teaching; } \\
\text { - } \text { application of the principles and methods of using Internet technologies in } \\
\text { teaching }\end{array}$ \\
\hline Work-relevant & $\begin{array}{l}\text { - } \text { professional skills to make an efficient teacher; } \\
\text { - } \text { analytical abilities and a desire to share acquired knowledge with other } \\
\text { participants of the educational process; } \\
\text { - } \text { making presentations of personal techniques and methods of using Internet } \\
\text { technologies in teaching at conferences, seminars, etc., contributing articles to } \\
\text { scientific journals }\end{array}$ \\
\hline Value & $\begin{array}{l}\text { - } \text { professional self-confidence; being demanding towards themselves and students; } \\
-\quad \text { tolerant and balanced management of the educational situation; } \\
\text { - } \text { ability to control their own emotions in educational situations; aesthetic behavior }\end{array}$ \\
\hline Creative & $\begin{array}{ll}- & \text { creativity in using Internet technologies; } \\
- & \text { desire to develop their own creative potential; } \\
- & \text { management of students' creative educational activities }\end{array}$ \\
\hline Result-reflexive & $\begin{array}{l}\text { - } \text { self-control, self-esteem, self-knowledge, self-education and self-assertion in } \\
\text { professional activities; } \\
\text { - } \text { ability to assess IT methods, techniques and tools used in education }\end{array}$ \\
\hline
\end{tabular}

As seen from Table 1, the motivational criterion includes teachers' interest in their profession, their motives for and needs of professional development, awareness of the social significance of teachers, the desire to develop teaching skills, to improve their professional knowledge and skills. This criterion indicators include the goals, motives for and needs of using Internet technologies in teaching, success achievement motivation, self-realization ability, the need to promote students' interest in the disciplines that are taught, the use of modern educational technologies, including Internet technologies, raising teachers' level of knowledge and skills in applying Internet technologies in teaching as well as development of teachers' computer literacy and information competence. 
The integrative criterion is a system of knowledge (professional, psychological, educational, methodological) about general educational and specific (related to specialized subjects) forms and methods of teaching and students' socialization as well as the knowledge necessary for efficient professional activity.

This criterion indicators include knowledge of foreign languages at a proficiency level, the ability to choose software to use in teaching and the application of principles and methods of using Internet technologies in education.

By the work-relevant criterion, we understand the teachers' skills that are necessary for efficient work in rapidly changing technological conditions. In terms of teachers' professional readiness, we distinguish the following groups of skills:

$\checkmark$ Gnostic skills, which are manifested in teachers' ability to acquire and improve knowledge, assess students' and their own personality. The highly developed gnostic skills imply the regular update of knowledge about the use of Internet technologies in education, studying colleagues' relevant experience, analysis of the process of teaching, formulation of the main objectives of education to meet the requirements of society, school and students;

$\checkmark$ Project skills, which imply teachers' ability to plan lessons in accordance with the needs of education using psychological knowledge, rational work methods and techniques, to plan their work on the development of students' informational competence and computer literacy, to use the Internet technologies-based forms and methods of professional self-development;

$\checkmark$ Constructive skills, which include teachers' ability to reach the goals of development of student groups or individual students, to choose the best methods and means of teaching, to select and optimally present educational materials using the Internet, to choose the forms and methods of using Internet technologies, to plan developing students' informational competence and computer literacy, and to determine the educational process management nature;

$\checkmark$ Organizational skills, which include teachers' ability to organize their own and students' activities in accordance with the goals of education, to encourage students' development of intellectual abilities and information competence, to stimulate students' positive behaviors, responsibility, initiative and activity, as well as to teach students the ways of organizing learning activities;

$\checkmark$ Communicative skills, which are made up of teachers' ability to use different mechanisms of formation of interpersonal relations, to create a friendly atmosphere in a classroom and among colleagues, to manage their emotions and control behavior when interacting with students and colleagues, and to organize teacher-parent Internet interactions (keeping e-diaries or chatting, etc.);

$\checkmark$ Didactic skills, which are characterized by the knowledge of modern technologies, including the Internet, and scientifically-grounded teaching methods and techniques to reach the objectives of education;

$\checkmark$ Managerial skills, which imply the ability to effectively manage the educational process;

$\checkmark$ Intellectual skills, which include the ability to analyze, generalize, systematize, classify and adapt the Internet information for teaching;

$\checkmark$ Research skills, which imply the ability to identify a problem, to plan research determining its goals, objectives, subject, hypothesis and methods, as well as to conduct experiments, process and analyze their results and make conclusions;

$\checkmark$ IT-specific skills, which are made up of the abilities to use computers and other equipment, to install software, to service computers, peripheral and other office equipment, to carry out minor repairs, to use IT for communication with colleagues, students and parents, to maintain and administer the school computer network, to use IT to assess students' knowledge and skills, to use networks and Internet technologies to familiarize students with new advances in science and technology, as well as to use educational software to interest students and promote gaining practical skills. 
The information, integrative and work-relevant criteria for determining teachers' readiness for the use of Internet technologies allow measuring the levels of teachers' theoretical knowledge. The content of the motivational, integrative and work-relevant criteria determines the strategy of teacher's professional behavior. The work-relevant criterion is based on a set of teachers' psychological and educational skills that characterize the implementation of the education strategy.

The value criterion of teachers' readiness for the use of Internet technologies is characterized by teachers' profession-relevant qualities and values. The indicators of this criterion include professional confidence, fastidiousness, tolerance, balanced management of the pedagogical situation, ability to control personal emotional state, and aesthetic behavior.

The creative criterion is characterized by teachers' qualities necessary for fruitful creative work. The indicators of the creative criterion comprise teachers' creativity, morality, responsibility, fairness, flexible thinking, vision of new problems and solutions, effective management of students' creative activities, creative use of Internet technologies in work, and creative self-development.

The result-reflexive criterion is characterized by teachers' ability to exercise control, self-control and self-assessment of their professional activities. The indicators of this criterion include control, self-control, self-esteem, self-knowledge, self-education, professional selfrealization, ability to analyze the effectiveness of methods, techniques and means of using Internet technologies in the educational process.

The above-mentioned criteria of teachers' readiness for the use of Internet technologies as well as their indicators allow measuring the following levels of teachers' readiness for the use of Internet technologies: low, medium, satisfactory and high.

The low level of teachers' readiness for the use of Internet technologies implies poor motivation to use Internet technologies, poor knowledge and skills in Internet technologies, low self-control and professional self-correction.

The medium level of teachers' readiness for the use of Internet technologies corresponds to teachers' awareness of their personal need to improve their knowledge of Internet technologies and their use in education. The medium level is characterized by reproduction of the relevant knowledge by a certain algorithm, uncertain actions, anxiety and hesitation while using Internet technologies in teaching.

The satisfactory level of teachers' readiness for the use of Internet technologies means that the teacher is self-motivated and proactive in gaining education-relevant knowledge and skills for use of Internet technologies, has partly-developed professionally important qualities, can predict, evaluate and adjust his/her professional activities, and assesses his/her performance and possibilities.

The high level corresponds to teachers' ability to develop the techniques and methods of education-relevant use of Internet technologies, strong work motivation, keen interest in the education-relevant use of Internet technologies, readiness for creative work, professional and personal self-development, thorough relevant theoretical and methodological knowledge and the ability to predict and anticipate the results of their professional activities.

Given the mathematical and statistical data, which meet the criteria of our study and have been used to test our research hypothesis, and the idea that any criterion used in the calculation (Pearson, Student, Mann-Whitney, Fisher, Dixon and others) should not exceed 1, we have found the scores (see Table 2), which will be used for further experimental data analysis [14].

In order to determine the levels of teachers' readiness to use Internet technologies in their work according to the above-discussed criteria, it is necessary to assess teachers' skills and abilities using relevant instruments, which include questionnaires, tests, and analyses of the results of their theoretical and practical work. Each criterion has a number of points with a maximum possible percentage (Table 2). 
Table 2

Assessment of teachers' readiness to use Internet technologies in their work

\begin{tabular}{|c|c|c|c|}
\hline Criteria & Indicators & Assessment instruments & Points, $\%$ \\
\hline \multirow{3}{*}{ Motivational } & $\begin{array}{l}\text { Motivation to use modern technologies, in } \\
\text { particular the Internet, in their work, } \\
\text { acquisition of knowledge about the Internet } \\
\text { and its use in education }\end{array}$ & \multirow{3}{*}{ Questionnaires, tests } & 1,100 \\
\hline & Self-realization ability & & 1,100 \\
\hline & $\begin{array}{l}\text { Need to promote students' interest in the } \\
\text { subject of teaching }\end{array}$ & & 1,100 \\
\hline \multirow{3}{*}{ Integrative } & $\begin{array}{l}\text { Knowledge of foreign languages at a } \\
\text { proficiency level }\end{array}$ & \multirow{3}{*}{$\begin{array}{l}\text { Tests, analysis of the } \\
\text { results of theoretical and } \\
\text { practical work }\end{array}$} & 1,100 \\
\hline & Ability to select software to use in teaching & & 1,100 \\
\hline & $\begin{array}{l}\text { Application of the principles and methods of } \\
\text { using Internet technologies in teaching }\end{array}$ & & 1,100 \\
\hline \multirow{3}{*}{ Work-relevant } & $\begin{array}{l}\text { Professional skills to make an efficient } \\
\text { teacher }\end{array}$ & \multirow{3}{*}{$\begin{array}{l}\text { Questionnaires, tests, } \\
\text { analysis of the results of } \\
\text { theoretical and practical } \\
\text { work }\end{array}$} & 1,100 \\
\hline & $\begin{array}{l}\text { Analytical abilities and a desire to share self- } \\
\text { acquired knowledge with other participants } \\
\text { of the educational process }\end{array}$ & & 1,100 \\
\hline & $\begin{array}{l}\text { Making presentations of personal techniques } \\
\text { and methods of using Internet technologies } \\
\text { in teaching at conferences, seminars, etc., } \\
\text { contributing articles to scientific journals }\end{array}$ & & 1,100 \\
\hline \multirow{4}{*}{ Value } & $\begin{array}{l}\text { Professional self-confidence; being } \\
\text { demanding towards themselves and students }\end{array}$ & \multirow{4}{*}{ Tests } & 1,100 \\
\hline & $\begin{array}{l}\text { Tolerant and balanced management of } \\
\text { educational situations }\end{array}$ & & 1,100 \\
\hline & $\begin{array}{l}\text { Control of their own emotions in educational } \\
\text { situations }\end{array}$ & & 1,100 \\
\hline & Aesthetic behavior & & 1,100 \\
\hline \multirow{3}{*}{ Creative } & Creativity in using Internet technologies & \multirow{3}{*}{$\begin{array}{l}\text { Questionnaires, analysis of } \\
\text { the results of theoretical } \\
\text { and practical work }\end{array}$} & 1,100 \\
\hline & Desire to develop personal creative potential & & 1,100 \\
\hline & $\begin{array}{l}\text { Management of students' creative } \\
\text { educational activities }\end{array}$ & & 1,100 \\
\hline \multirow{2}{*}{ Result-reflexive } & $\begin{array}{l}\text { Self-control, self-esteem, self-knowledge, } \\
\text { self-education and self-assertion in } \\
\text { professional activities }\end{array}$ & \multirow{2}{*}{ Questionnaires, tests } & 1,100 \\
\hline & $\begin{array}{l}\text { Ability to assess Internet technologies, } \\
\text { methods, techniques and tools used in } \\
\text { education }\end{array}$ & & 1,100 \\
\hline
\end{tabular}

\section{CONCLUSIONS AND FOLLOW-UP RESEARCH}

Substantiation of criteria and indicators of formation of secondary school teachers' readiness for the use of Internet technologies in their professional activity is a pressing pedagogical problem today. Analysis of scientific sources showed that domestic and foreign scientists are working on this problem, which gave us the ground to determine the content of the basic concepts of our research - "criterion", "indicator" and "level".

In our opinion, Internet technologies are a set of basic Internet services, cloud technologies and web technologies. The concept of Internet services denotes the Internet components that provide information exchange processes on the Internet, which include: WWW, e-mail, search engines, video conferencing, teleconferencing, forums, chats, FTP, Telnet, Internet pagers, etc. Thus, Internet technology is an effective means of communication between all educational process participants. 
The article discusses the criteria and indicators for determining teachers' readiness to use Internet technologies in their work (motivational, integrative, work-relevant, value, creative and result-reflexive). One of the components of teachers' professionalism is proved to be their readiness for the use of Internet technologies, which includes the described criteria. The levels of these criteria can serve as indicators of teachers' professional efficiency as a result of their training or refresher training at education institutions. The development of teachers' readiness for the use of Internet technologies is an important prerequisite of a highstandard education in Ukraine.

It has been proved that sound criteria, indicators and levels of formation of secondary school teachers' readiness for the use of Internet technologies in their professional activity are interconnected and only a complex study can ensure the objectivity of their further diagnosing. The results of our analysis have proved a need for new approaches to teaching, students' socialization and development, the optimization and modernization of the content, forms, methods and means of education through the use of Internet technologies in education in order to develop students as efficient future professionals. The follow-up study will focus on developing the psychodiagnostic techniques for assessing teaching staff's readiness to use Internet technologies in their professional activities.

Text of the article was accepted by Editorial Team 29.12.2019

\section{REFERENCES (TRANSLATED AND TRANSLITERATED)}

[1] Pukhovska, L. P. Teacher training in Western Europe: similarities and differences. Kyiv, p. 180, 1997. (in Ukrainian).

[2] Bilousova, L. Some aspects of teacher training for the implementation of the Internet technologies didactic potential in the practice of teaching. Psychological and teaching problems of rural schools, № 42(1), pp. 713, 2018. [Online].Available: http://nbuv.gov.ua/UJRN/Ppps_2012_42\%281\%29_3 (in Ukrainian).

[3] Kryshtof, S. D. Internet support for the educational process in natural sciences and mathematics in the perspective of the implementation of ideas of humanization of education, Collection of scientific works "Pedagogical education: theory and practice", № 9, Kamyanets-Podilsky, p. 268, 2011. (in Ukrainian).

[4] Baccelli, Fr., Crowcroft, J. Future Internet Technology, ERCIM NEWS, no. 77, pp. 16-18, 2009. [Online]. Available: https://ercim-news.ercim.eu/images/stories/EN77/EN77-web.pdf (in English).

[5] Bykov, V. Yu. Problems and prospects of informatization of the education system in Ukraine, Naukovy chasopys NPU named by M. Dragomanov, Seria № 2, Komputerno-orientovani systemy navchannya: $z b$. nauk.. pr., Kyiv: NPU named by M. Dragomanov, № 13(20), pp. 3-18, 2012. (in Ukrainian).

[6] Baun, Chr., Kunze, M., Nimis, J., Tai, St. Cloud Computing: Web-basierte dynamische IT-Services, Springer-Verlag Berlin Heidelberg, 2011. (in German).

[7] Nadel-Chervinskaya, M. A., Chervinsky, P. P. Great Dictionary of Foreign Words. Rostov n/D: Phoenix, V. 2, p. 528, 1995. (in Russian).

[8] Fedoruk, A. L. "Informatics teachers' specialized class work readiness criteria and indicators". Visnyk Chernigivskogo natsionalnogo ped. un-tu im. T. G. Shevchenka, № 130, pp. 223-227, 2015. (in Ukrainian).

[9] Ozhegov, S. Y. The dictionary of Russian language. Moscow, p. 917, 1991. (in Russian).

[10] Vitvytska, S. S. Methodological foundations of graded teacher education. Visnyk Zhytomyrskogo derzh. untu im. Ivana Franka, № 21, pp. 8-11, 2005. (in Ukrainian).

[11] Duschenko, O. Future informatics teachers' Internet technologies usage readiness. Naukovyi visnyk Melitopolskogo derzh. ped. un-tu, № 1, pp. 327-333, 2015. (in Ukrainian).

[12] Dubinina, O. V., Hrytsiak, L. D. Formation Model of Future Progect Managers Information Culture. American Journal of Engineering Research (AJER), vol. 8, Iss. 2, pp. 72-77, 2019. (in English).

[13] Dubinina, O. V., Hrytsiak, L. D. Use of information technologies in future project managers' activities. Information technologies and learning tools, vol. 63, № 1, pp. 107-115, 2018. (in Ukrainian).

[14] Vasylenko, O. A. Mathematical and statistical methods of analysis in applied research. Odessa, p. 166, 2011. (in Ukrainian).

[15] Pobirchenko, N. Innovative approaches to teacher training in the context of higher teacher education reform. Native school, № 3, pp. 3-5, 2003. (in Ukrainian).

[16] Staryeva, A. M. Analysis of foreign development strategies experience in teacher training. Bulletin of Mykolaiv State University of Teaching, № 5, pp. 92-100, 2003. (in Ukrainian).

[17] Stolyarenko, O. V. Educational activity modeling in specialists' training: manual. Vinnytsa, p. $196,2015$. (in Ukrainian) 


\title{
КРИТЕРІЇ ТА ПОКАЗНИКИ ФОРМУВАННЯ ГОТОВНОСТІ ВЧИТЕЛІВ ЗАКЛАДІВ ЗАГАЛЬНОЇ СЕРЕДНЬОЇ ОСВІТИ ДО ЗАСТОСУВАННЯ ІНТЕРНЕТ-ТЕХНОЛОГІЙ У ПРОФЕСІЙНІЙ ДІЯЛЬНОСТІ
}

\author{
Кравчинська Тетяна Сергіївна \\ Навчально-наукового інституту менеджменту та психології \\ ДЗВО «Університет менеджменту освіти» НАПН України, м. Київ, Україна \\ ORCID ID 0000-0002-7521-3508 \\ tatyana.krav@ukr.net
}

кандидат педагогічних наук, докторант кафедри публічного управління і проєктного менеджменту

\section{Сіданіч Ірина Леонідівна}

доктор педагогічних наук, доцент, професорка кафедри педагогіки, адміністрування і соціальної роботи Навчально-наукового інституту менеджменту та психології

ДЗВО «Університет менеджменту освіти» НАПН України, м. Київ, Україна

ORCID ID 0000-0002-2992-3808

2363395@ukr.net

\section{Павленко Інна Олександрівна}

кандидат педагогічних наук, старша викладачка кафедри спортивних дисциплін і фізичного виховання Сумський державний педагогічний університет ім. А. С. Макаренка, м. Суми, Україна

ORCID ID 0000-0001-5707-7509

byyf1202@ukr.net

\section{Дубініна Оксана Володимирівна}

кандидат педагогічних наук, доцент кафедри публічного управління і проєктного менеджменту Навчально-наукового інституту менеджменту та психології

ДЗВО «Університет менеджменту освіти» НАПН України, м. Київ, Україна

ORCID ID 0000-0002-5405-8502

o_dybinina@ukr.net

\begin{abstract}
Анотація. У статті обгрунтовано критерії та показники формування готовності вчителів закладів загальної середньої освіти до застосування Інтернет-технологій у професійній діяльності. Сучасне реформування освітньої галузі та впровадження нового змісту освіти вимагає від учителів використання інноваційних методів та електронних навчальних посібників, що потребує нових підходів до навчання вчителів під час підвищення кваліфікації та самоосвітньої діяльності в міжатестаційний період. 3 урахуванням змісту і специфіки педагогічної діяльності вчителів закладів освіти розглянуто педагогічні умови розвитку їх готовності до застосування Інтернет-технологій та розкрито педагогічну доцільність використання Інтернет-технологій у професійній діяльності вчителя. Вибір відповідних критеріїв і показників здійснено 3 урахуванням специфіки професійної діяльності вчителів закладів загальної середньої освіти та схарактеризовано мотиваційний, інтеграційний, діяльнісний критерії; визначено гностичні, проєктувальні, конструктивні, організаційні, комунікативні, дидактичні, управлінські, інтелектуальні, дослідницькі та фахові вміння, які є визначальними в професійній готовності вчителя. Підкреслено, що зміст мотиваційного, інтеграційного та діяльнісного критеріїв зумовлює стратегію професійної поведінки вчителя в закладі освіти. Діяльнісний критерій заснований на комплексі психолого-педагогічних умінь і навичок і характеризує реалізацію цієї стратегії. На основі виявлених критеріїв готовності вчителів закладу освіти до застосування Інтернеттехнологій у професійній діяльності, а також показників їх прояву виокремлено низький, середній, достатній і високий рівні визначення готовності вчителів закладу освіти до застосування Інтернет-технологій у професійній діяльності. Показано, що ці критерії та їх показники надають можливість у подальшому отримати емпіричні дані щодо прогнозування результатів дослідження та 3'ясувати основні педагогічні аспекти створення авторської технології формування готовності вчителів закладів загальної середньої освіти до застосування Інтернет-технологій у професійній діяльності.
\end{abstract}

Ключові слова: учителі; професійна діяльність; Інтернет-технології; критерії, показники та рівні готовності до використання Інтернет-технологій. 


\title{
КРИТЕРИИ И ПОКАЗАТЕЛИ СФОРМИРОВАННОСТИ ГОТОВНОСТИ УЧИТЕЛЕЙ ЗАВЕДЕНИЙ ОБЩЕГО СРЕДНЕГО ОБРАЗОВАНИЯ К ПРИМЕНЕНИЮ ИНТЕРНЕТ-ТЕХНОЛОГИЙ В ПРОФЕССИОНАЛЬНОЙ ДЕЯТЕЛЬНОСТИ
}

\author{
Кравчинская Татьяна Сергеевна \\ кандидат педагогических наук, докторант кафедры публичного управления и проектного менеджмента \\ Учебно-научного института менеджмента и психологии \\ ГУВО «Университет менеджмента образования» НАПН Украины, г. Киев, Украина \\ ORCID ID 0000-0002-7521-3508 \\ tatyana.krav@ukr.net
}

\section{Сиданич Ирина Леонидовна}

доктор педагогических наук, доцент, профессор кафедры педагогики, администрирования и социальной роботы Учебно-научного института менеджмента и психологии

ГУВО «Университет менеджмента образования» НАПН Украины, г. Киев, Украина

ORCID ID 0000-0002-2992-3808

2363395@ukr.net

\author{
Павленко Инна Александровна \\ кандидат педагогических наук, \\ старший преподаватель кафедры спортивных дисциплин и физического воспитания \\ Сумской государственный педагогический университет им. А. С. Макаренко, г. Сумы, Украина \\ ORCID ID 0000-0001-5707-7509 \\ byyf1202@ukr.net
}

Дубинина Оксана Владимировна

кандидат педагогических наук, доцент кафедры публичного управления и проектного менеджмента Учебно-научного института менеджмента и психологии

ГУВО «Университет менеджмента образования» НАПН Украины, г. Киев, Украина

ORCID ID 0000-0002-5405-8502

o_dybinina@ukr.net

\begin{abstract}
Аннотация. В статье обоснованы критерии и показатели сформированности готовности учителей заведений общего среднего образования к применению Интернет-технологий в профессиональной деятельности. Современное реформирование образования и внедрение нового содержания образования требуют от учителей использования инновационных методов и электронных учебников, требуются новые подходы к обучению учителей при повышении квалификации и самообразовательной деятельности в межаттестационный период. С учетом содержания и специфики педагогической деятельности учителей учебных заведений рассмотрено педагогические условия развития их готовности к применению Интернет-технологий и раскрыто педагогическую целесообразность использования Интернет-технологий в профессиональной деятельности учителя. С учетом специфики профессиональной деятельности учителей заведений общего среднего образования осуществлен выбор соответствующих критериев и показателей и охарактеризованы мотивационный, интеграционный, деятельностный критерии; выделены гностические, проектировочные, конструктивные, организационные, коммуникативные, дидактические, управленческие, интеллектуальные, исследовательские и профессиональные умения, которые являются определяющими в профессиональной готовности учителя. Доказано, что мотивационный, интеграционный и деятельностный критерии характеризуют стратегию профессионального поведения учителя в учебном заведении. Деятельностный критерий, основанный на комплексе психолого-педагогических умений и навыков, характеризует реализацию этой стратегии. На основе выявленных критериев готовности учителей учебного заведения к применению Интернет-технологий в профессиональной деятельности, а также показателей их проявления выделены низкий, средний, достаточный и высокий уровни определения готовности учителей учебного заведения к применению Интернеттехнологий в профессиональной деятельности. Показано, что эти критерии и их показатели дают возможность в дальнейшем получить эмпирические данные по прогнозированию результатов исследования и выявить основные педагогические аспекты разработки авторской технологии формирования готовности учителей заведений общего среднего образования к применению Интернет-технологий в их профессиональной деятельности.
\end{abstract}

Ключевые слова: учителя; профессиональная деятельность; Интернет-технологии; критерии, показатели и уровни готовности к использованию Интернет-технологий.

\section{(c) BY-NC-SA}

This work is licensed under Creative Commons Attribution-NonCommercial-ShareAlike 4.0 International License. 